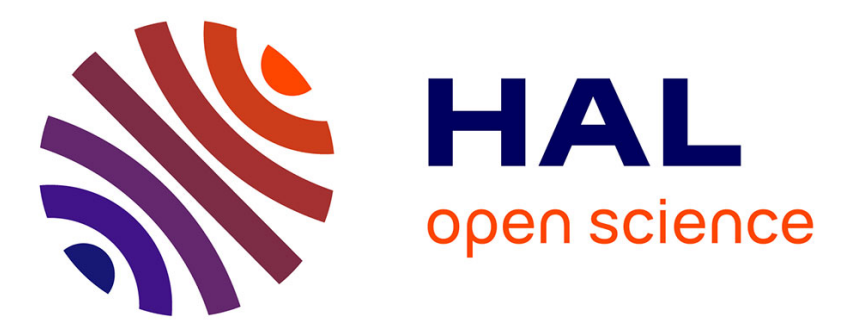

\title{
Identification of various laccases induced by anthracene and contribution to its degradation in a Mediterranean coastal pine litter
}

Leila Qasemian, Daniel Guiral, Maya Belghazi, Elisée Ferré, Raphaël Gros, Anne Marie Farnet da Silva

\section{To cite this version:}

Leila Qasemian, Daniel Guiral, Maya Belghazi, Elisée Ferré, Raphaël Gros, et al.. Identification of various laccases induced by anthracene and contribution to its degradation in a Mediterranean coastal pine litter. Chemosphere, 2011, 84 (10), pp.1321-1328. 10.1016/j.chemosphere.2011.05.021 . hal-02075884

\section{HAL Id: hal-02075884 \\ https://hal.science/hal-02075884}

Submitted on 21 Mar 2019

HAL is a multi-disciplinary open access archive for the deposit and dissemination of scientific research documents, whether they are published or not. The documents may come from teaching and research institutions in France or abroad, or from public or private research centers.
L'archive ouverte pluridisciplinaire HAL, est destinée au dépôt et à la diffusion de documents scientifiques de niveau recherche, publiés ou non, émanant des établissements d'enseignement et de recherche français ou étrangers, des laboratoires publics ou privés. 


\title{
Identification of various laccases induced by anthracene and contribution to its degradation in a Mediterranean coastal pine litter
}

\author{
Leila Qasemian $^{\mathrm{a}, *}$, Daniel Guiral ${ }^{\mathrm{a}}$, Maya Belghazi ${ }^{\mathrm{b}}$, Elisée Ferré ${ }^{\mathrm{a}}$, Raphaël Gros ${ }^{\mathrm{a}}$, Anne-Marie Farnet ${ }^{\mathrm{a}}$ \\ a Equipe Ecologie Microbienne et Biotechnologies, UMR CNRS IRD 6116, Institut Méditerranéen d'Ecologie et de Paléoécologie, Faculté des Sciences et Techniques de St. \\ Jérôme, Université Paul Cézanne, 13397 Marseille, France \\ ${ }^{\mathrm{b}}$ Centre d'Analyse Protéomique de Marseille, IFR Jean Roche, 51 Bd Pierre Dramard, 13916 Marseille, Cedex 20, France
}

Keywords:

Anthracene

Chronic pollution

Laccase sequence

Nano-LC-MS/MS

Pinus halepensis litter

\begin{abstract}
A B S T R A C T
Mediterranean coastal ecosystems are known to be highly subject to natural and anthropic environmental stress. In this study, we examine the effects of anthracene as a common pollutant on the total microbial communities from a Pinus halepensis litter of a typical Mediterranean coastal site (Les Calanques, Marseille). The main objective was to identify the microbial factors leading the resilience of this ecosystem. Two questions were addressed: (i) how lignin-degrading enzymes (Laccase, Lignin-peroxidase and Mn-peroxidase) are affected by the presence of this molecule, (ii) whether the indigenous consortia are involved in its degradation in mesocosms under favorable incubation conditions $\left(25^{\circ} \mathrm{C}, 60 \% \mathrm{WHC}\right)$ and after different time intervals ( 1 and 3 month(s)). We found a strong increase in laccase production in the presence of anthracene after 3 months, together with anthracene degradation $(28 \% \pm 5)$. Moreover 9,10-anthraquinone is detected as the product of anthracene oxidation after 3 months. However neither lignin-peroxidase activity nor Mn-peroxidase activity is detected. Laccase proteins directly extracted from litter were sequenced via Nano-LC-MS/MS and reveal twelve different peptide sequences induced by the presence of anthracene in the mesocoms. Our study confirms the major detoxification role of this enzymatic system and highlights the high degradation potential of fungal species inhabiting $P$. halepensis litter, a factor in the resilience of Mediterranean ecosystems.
\end{abstract}

\section{Introduction}

Due to the constant increase in environmental pollution, there is a growing interest in the microbial degradation of polycyclic aromatic hydrocarbons (PAHs). These molecules, considered major environmental pollutants (Johnsen and Karlson, 2007; Sorgi, 2007; Wilck, 2007), are persistent and toxic organic pollutants which have mutagenic and/or carcinogenic effects on living organisms (Sorgi, 2007). Because the Mediterranean ecosystem is subject to various natural and anthropogenic pressures e.g. Mediterranean climate with severe summer drought, urban pollution (De Nicola et al., 2005), studying the role of microbial communities in degrading environmental pollutants offers valuable insights into the resilience potential of Mediterranean ecosystems.

The massif of Marseilleveyre (Bouches du Rhône, France) is located in a peri-urban area subjected to strong anthropogenic pollution (industrial activities, transports, incinerators, etc.) from the city of Marseille (about 850000 inhabitants). In this study, we examine the potential of microbial communities from a Pinus halepensis litter, collected in this area, to transform anthracene, a molecule commonly found in PAH pollution. P. halepensis

\footnotetext{
* Corresponding author.

E-mail address: leila_qasemian@yahoo.com (L. Qasemian).
}

is a pioneer tree species in Mediterranean coastal regions (Quézel and Médail, 2003). Its litter contains high proportion of phenolic compounds, thus potentially favoring the development of lignindegrading microorganisms, especially white-rot fungi (Valentín et al., 2010). They are known to produce phenoloxidases (Baldrian, 2006; Sinsabaugh, 2010): lignin peroxidase (LiP) (Hammel et al., 1986), manganese peroxidase (MnP) (Sack et al., 1997) and laccase (Collins et al., 1996). Previous studies have shown that laccases (benzenediol: oxygen oxidoreductase, EC 1.10.3.2) produced by white-rot fungi isolated from these particular ecosystems (Farnet et al., 2009, 2011) were able to transform various aromatic pollutants (Potin et al., 2004; Pozdnyakova et al., 2006; Majeau et al., 2010; Oria-de-Rueda et al., 2010). It therefore seems likely that this enzyme has major potential for anthracene transformation in Mediterranean coastal litters.

Our objectives were (i) to demonstrate the capacity of autochthonous microbial communities to transform anthracene under semi-natural conditions, (ii) to clarify the potential role of phenoloxidases in this process and (iii) to potentially identify the laccase produced under these conditions via protein sequencing.

Mesocosms with $P$. halepensis litter were subject to anthracene inputs: anthracene disappearance was monitored over a 3-month incubation period and different phenoloxidase activities (LiP, $\mathrm{MnP}$ and Laccase) were monitored throughout incubation. Particu- 
lar attention was paid to laccase isoform production, since these enzymes are known to be induced by various aromatic compounds (Farnet et al., 1999; Teng et al., 2010).

\section{Materials and methods}

\subsection{Litter sampling}

A composite sampling was performed in November 2009 from partially degraded litter (horizon L) of Aleppo pine (P. halepensis L.) located on the French Mediterranean coast (Massif de Marseilleveyre, Marseille) ( $\left.43^{\circ} 12^{\prime} 34^{\prime \prime} \mathrm{N}, 5^{\circ} 21^{\prime} 36^{\prime \prime} \mathrm{E}\right)$. Five samplings were randomly performed in a $100 \mathrm{~m}^{2}$ area. The litter was sieved at $2 \mathrm{~mm}$ mesh size, homogenized and stored overnight at $4{ }^{\circ} \mathrm{C}$ before being used in mesocosms.

\subsection{Mesocosm preparation}

Litter was placed in 2.6 L glass jars $(25 \times 20 \times 7 \mathrm{~cm})$ containing $50 \mathrm{~g}$ of litter (dry weight, DW) per mesocosm, covered with pierced lids to favor oxygen diffusion. Anthracene mesocosms (ANT) were prepared as follows: $40 \mathrm{mg}$ of anthracene was dissolved in dichloromethane and added to a sub-sample of litter (10 g DW of litter) in order to minimize the harmful side-effects of solvent. After dichloromethane evaporation, the subsample was mixed with the litter of the mesocosm (40 g DW). Three different control mesocosms were also performed: a control mesocosm (C) i.e. litter without any treatment, a solvent control mesocosm (S-C) containing a sub-sample of litter treated with solvent alone and an abiotic control (A-C) using sterilized litter. Litter was sterilized three times by successive autoclaving at $120^{\circ} \mathrm{C}$ for $20 \mathrm{~min}$. This latter experiment was performed to assess the potential chemical oxidation of anthracene or its adsorption to litter particles. Each mesocosm type (C, S-C, A-C, ANT) was realized in triplicate $(n=3)$ and incubated at $25{ }^{\circ} \mathrm{C}$ in the dark both for 1 - and for 3-months. Thus, for each incubation time, a total of 12 mesocosms were realized. Humidity of samples was maintained constant over incubation at $60 \%$ of the $\mathrm{WHC}_{\max }$

\subsection{Anthracene extraction and quantification with high performance liquid chromatography (HPLC)}

Anthracene was extracted from $20 \mathrm{~g}$ of litter from each mesocosm after 1- and 3-month incubation, using $200 \mathrm{~mL}$ of dichloromethane as solvent. The mixture was shaken twice at $500 \mathrm{rpm}$ for $20 \mathrm{~min}$. The extract was filtered and the solvent was then evaporated using a roto-vap chamber (Heidolf) and anthracene was dissolved in acetone. Associated debris were reduced via filtering and rinsed with acetone to a final volume of $100 \mathrm{~mL}$.

Anthracene was quantified with HPLC (Waters) equipped with a C18 Reverse Phase column (Merck, $4.6 \times 250 \mathrm{~mm}$ ). The following gradient system was used: solvent $\mathrm{A}$, water/trifluoroacetic acid $0.1 \%$ acetonitrile $90 / 10 \mathrm{v} / \mathrm{v}$, solvent $\mathrm{B}$, water/trifluoro acetic acid $0.1 \%$ acetonitrile $95 / 5 \mathrm{v} / \mathrm{v}$, gradient $=5-15 \mathrm{~min}, A 100 \%$ to $B$ 100\%; $15-25$ min B $100 \%$ (flow rate $1 \mathrm{~mL} \mathrm{~min}^{-1}$ ). A calibration curve of anthracene was performed using 1, 2, 3, 4 and 5 nmoles of the compound. Peaks were identified based on matching retention time at $254 \mathrm{~nm}$ and UV spectra with those of anthracene and 9, 10-anthraquinone standards.

\subsection{Enzyme activities}

Proteins were extracted from mesocosms following a protocol modified from Criquet et al. (1999). Briefly, $10 \mathrm{~g}$ of litter was added to $200 \mathrm{ml} \mathrm{CaCl} \cdot 2 \mathrm{H}_{2} \mathrm{O}(200 \mathrm{mM})$ and $0.1 \%$ Tween 80 , and then shaken for $1 \mathrm{~h}$ (500 rpm). The floating debris were removed, the extract was centrifuged ( $3000 \mathrm{~g}$ for $20 \mathrm{~min}$ ) and the supernatant was filtered (Whatman $\mathrm{GF} / \mathrm{C}$ ). The filtrate was concentrated by dialysis membrane (12-14 KDa) using poly-ethylene glycol (PEG) and proteins were solubilized by adding $15 \mathrm{~mL}$ of BisTris buffer (20 mM, pH 6). Laccase activity was measured according to Harkin and Obst (1973) by monitoring the oxidation of syringaldazine [N,N'-bis-(3,5-dimethoxy-4-hydroxybenzylidene)hydrazine] to quinone $\left(\varepsilon^{\mathrm{M}}=65000 \mathrm{M}^{-1} \mathrm{~cm}^{-1}\right)$ at $525 \mathrm{~nm}$. Both Lignin peroxidase (LiP) and Mn peroxidase (MnP) activities were quantified using 2-7 diaminofluorene $75 \mu \mathrm{M}$ as substrate with $\mathrm{H}_{2} \mathrm{O}_{2}$ and with both $\mathrm{H}_{2} \mathrm{O}_{2}$ and $\mathrm{MnSO}_{4}(75 \mu \mathrm{M})$ respectively (Farnet et al., 2011). Absorption was monitored at $600 \mathrm{~nm}\left(\varepsilon^{\mathrm{M}}=10228 \mathrm{M}^{-1} \mathrm{~cm}^{-1}\right)$. LiP activity and $\mathrm{MnP}$ activities were respectively calculated as follows: Activity with $\mathrm{H}_{2} \mathrm{O}_{2}$ - Activity without $\mathrm{H}_{2} \mathrm{O}_{2}$ and Activity with $\mathrm{H}_{2} \mathrm{O}_{2}$ and $\mathrm{MnSO}_{4}$ - Activity with $\mathrm{H}_{2} \mathrm{O}_{2}$ - Activity without $\mathrm{H}_{2} \mathrm{O}_{2}$. The reaction mixture consisted of $300 \mu \mathrm{L}$ of enzyme extract with $700 \mu \mathrm{L}$ of acetate buffer $100 \mathrm{mM}$, pH 4.5 incubated in $30^{\circ} \mathrm{C}$. One unit (U) of enzyme activity is defined as the amount of enzyme that oxidizes $1 \mu$ mole of substrate per $h$. The significance of differences in enzyme activities between the treatment was tested by nonparametric multiple comparison of Kruskal-Wallis. Each replicate was considered as independent sample and compared over time. XLSTAT Vs7.1 (Addinsoft, France) was used for statistical analysis and $P$-value $<0.05$ was considered as significant.

\subsection{Protein electrophoresis}

The protein extracts obtained from mesocosms were subjected to polyacrylamide gel electrophoresis (PAGE), carried out according to Laemmli (1970). A Mini-Protean II electrophoresis cell (Bio-Rad) was used with $4 \%$ stacking gel and $10 \%$ separating gel at $220 \mathrm{~V}$. The protein extracts from each mesocosm condition (triplicate) were loaded onto the gel using $200 \mathrm{ng}$ of proteins. The gels were soaked in sodium acetate buffer $100 \mathrm{mM}$, pH 4.5 and stained to reveal a laccase activity using $p$-phenylenediamine as a substrate at $0.1 \%(\mathrm{w} / \mathrm{v})$. For protein sequencing, the triplicates from anthracene mesocosms were pooled and concentrated at $4000 \mathrm{~g}$ for $10 \mathrm{~min}$ using a MACROSEP tube with a membrane of $10 \mathrm{KDa}$ cut off (Pall Corporation, Life Science, USA). The concentrated samples were loaded twice into two separated lanes (12\% separating gel). After migration, the gel was divided into two halves: one gel was stained using the standard Coomassie blue protocol and the other using laccase activities as previously described. The protein bands matching those stained by laccase activity were cut and subjected to sequencing.

\subsection{Protein sequencing by mass spectrometry (LC/MS/MS)}

Sequence information from protein bands separated by 1D gel electrophoresis was obtained by mass spectrometry. The Coomassie blue stained bands were excised with a scalpel blade and cut into small blocks. The gel blocks were subjected to automatic trypsin hydrolysis using a Freedom EVO100 (Tecan) digestion robot. Basically, gels were rinsed with water and acetonitrile then reduced with DTT (Sigma), and alkylated with iodoacetamide (Sigma) and incubated overnight at $37^{\circ} \mathrm{C}$ in a microtube with $12.5 \mathrm{ng} \mu \mathrm{L}^{-1}$ of trypsin (Sequencing grade, Roche) in $25 \mathrm{mM}$ $\mathrm{NH}_{4} \mathrm{HCO}_{3}$ as previously described (Shevchenko et al., 1996). The tryptic fragments were extracted, dried, reconstituted with $0.1 \%$ formic acid and sonicated for $10 \mathrm{~min}$.

Tryptic peptides were sequenced by nano-LC-MS/MS (CapLC coupled to a Q-TOF-Ultima equipped with a nano-ESI source; Waters Micromass) in the data-dependent acquisition mode (four most intense ions per cycle, $1 \mathrm{~s}$ MS scan, $10 \mathrm{~s}$ maximum MSMS scan, and 60 s dynamic exclusion). Only doubly and triply charged 
Table 1

Laccase activities (U. g dw-1) of Pinus halepensis litter after 1- and 3-month incubations in control C, solvent control S-C, mesocosm with $40 \mathrm{mg}$ of anthracene ANT. For each mesocosm at each time, values followed by different letters (a to d) differ significantly according to Kruskal-Walis test and Dunn procedure for multiple comparisons of means $(p<0.05)$.

\begin{tabular}{lllc}
\hline \multicolumn{4}{l}{ Laccase activity $\left(\mathrm{U} . \mathrm{g} \mathrm{dw}^{-1}\right)$} \\
\cline { 2 - 4 } Mesocosms & $\mathrm{t}_{0}$ & 1-month & 3-months \\
\hline C & $0.027 \pm 0.006^{\mathrm{cd}}$ & $0.004 \pm 0.001^{\mathrm{ab}}$ & $0.008 \pm 0.004^{\mathrm{c}}$ \\
S-C & & $0.002 \pm 0.001^{\mathrm{a}}$ & $1.36 \pm 073^{\mathrm{d}}$ \\
ANT & & $0.004 \pm 0.000^{\mathrm{ab}}$ & $6.68 \pm 099^{\mathrm{d}}$ \\
\hline
\end{tabular}

ions were selected as precursors over a mass range of $400-1300 \mathrm{~m} / \mathrm{z}$. The collision energy was selected depending on the precursor ion mass and charge and the argon pressure in the collision cell was set at around 5-5.5 $\times 10^{-5}$ Torr. The source temperature and pressure were respectively $80^{\circ} \mathrm{C}$ and 2.8 Torr and the capillary voltage was $3.2 \mathrm{kV}$. The mass spectrometer was calibrated using the fragmentation spectrum at $28 \mathrm{eV}$ of Glu-fibrinopeptide (Sigma) at $100 \mathrm{fmol} \mathrm{mL}^{-1}$ in $50 / 50$ water/ACN $0.1 \%$ formic acid. The protein digests were loaded on a precolumn (NanoEaseTM180 mm i.d $\times 23.5 \mathrm{~mm}$, AtlantisTM dC18, Waters) and desalted with $0.1 \%$ formic acid for $5 \mathrm{~min}$ at $25 \mathrm{~mL} \mathrm{~min}{ }^{-1}$ on line with a C18 column (AtlantisTM dC18 $75 \mathrm{~mm}$ i.d $\times 150 \mathrm{~mm}$ NanoEaseTM, $3 \mathrm{~mm}$, 100 Á Waters). Peptides were eluted on a 5-60\% linear gradient with water/acetonitrile $98 / 2(\mathrm{v} / \mathrm{v})$ containing $0.1 \%$ formic acid in buffer $A$ and water/acetonitrile $20 / 80(\mathrm{v} / \mathrm{v})$ containing $0.1 \%$ formic acid in buffer B in $90 \mathrm{~min}$ at a flow rate of $180-200 \mathrm{~nL} \mathrm{~min}^{-1}$. The column outlet was connected via a fused silica capillary $(20 \mathrm{~mm}$ ID) to the nano-LC probe (Waters Micromass) and using another fused silica capillary as emitter (10 mm ID).

Data were processed using ProteinLynx Global server 2.2 (PLGS 2.2 , background noise subtraction 35\%, smooth 3/2 SavitzkyGolay and fast deisotoping) and matched to the NCBI non-redundant protein database (all taxa, version 20100411 containing 10820686 sequences) and to the GenBank ESTs database (EST_others, others_xyzzy containing 56245770 sequences). The search engine used was Mascot version 2.2 (Matrix Science, London, http:// www.matrixscience.com) with the following search parameters: trypsin specificity, one missed cleavage, variable carbamidomethyl cysteine and oxidation of Met, and 0.1 Da mass tolerance on both precursor and fragment ions. De novo sequences were blasted against non-redundant database (nrdb95) using MS-BLAST software (http://dove.embl-heidelberg.de/Blast2/msblast.html). Only hits with significant high score peptide (HSP) according to Shevchenko et al. (2001) were taken into account. Briefly, sequence homology was considered as significant when the sum of HSPs of $n$ peptides was equal to or higher than the threshold of the table from Shevchenko et al. (2001) for $n$ reported HSPs.

\section{Results}

In examining anthracene degradation yields, our first concern was to distinguish between abiotic and biotic phenomena. The extraction tests performed immediately after anthracene was added to the litter yielded of $92 \% \pm 7 \%$. The abiotic controls $(A-C)$ with sterile litter incubated with anthracene for 1 and 3 month(s) showed extraction yields of $57 \% \pm 3 \%$. The yield decrease may be due to anthracene evaporation or adsorption on litter, which mainly occurred during the first month of incubation since no differences in yields were observed between 1 and 3-month incubation periods. Yields from the microbiologically active mesocosms (the ANT mesocosms) showed no biotic degradation after 1 month but $28 \% \pm 5 \%$ anthracene degradation after 3 months. We also identified 9,10-anthraquinone as the product of anthracene oxidation in the HPLC elution profile (Fig. 1) after a 3-month incubation.

Laccase activities were measured in each mesocosm (C, S-C, ANT) after 1- and 3-month incubations (Table 1). Whatever the mesocosms considered, a slight decrease in laccase activities was observed after a 1-month incubation. In control mesocosms, no significant variation in laccase activities was observed over time between 1- and 3-month incubations, whereas laccase activities in ANT mesocosms or S-C mesocosms dramatically increased at 3-month incubation. Indeed, after this incubation time, laccase activities were 170- and 800-fold higher in mesocoms S-C and ANT respectively than those in mesocosms $C$. Laccase activities in mesocosms $\mathrm{S}-\mathrm{C}$ were enhanced to a lesser extent than those in
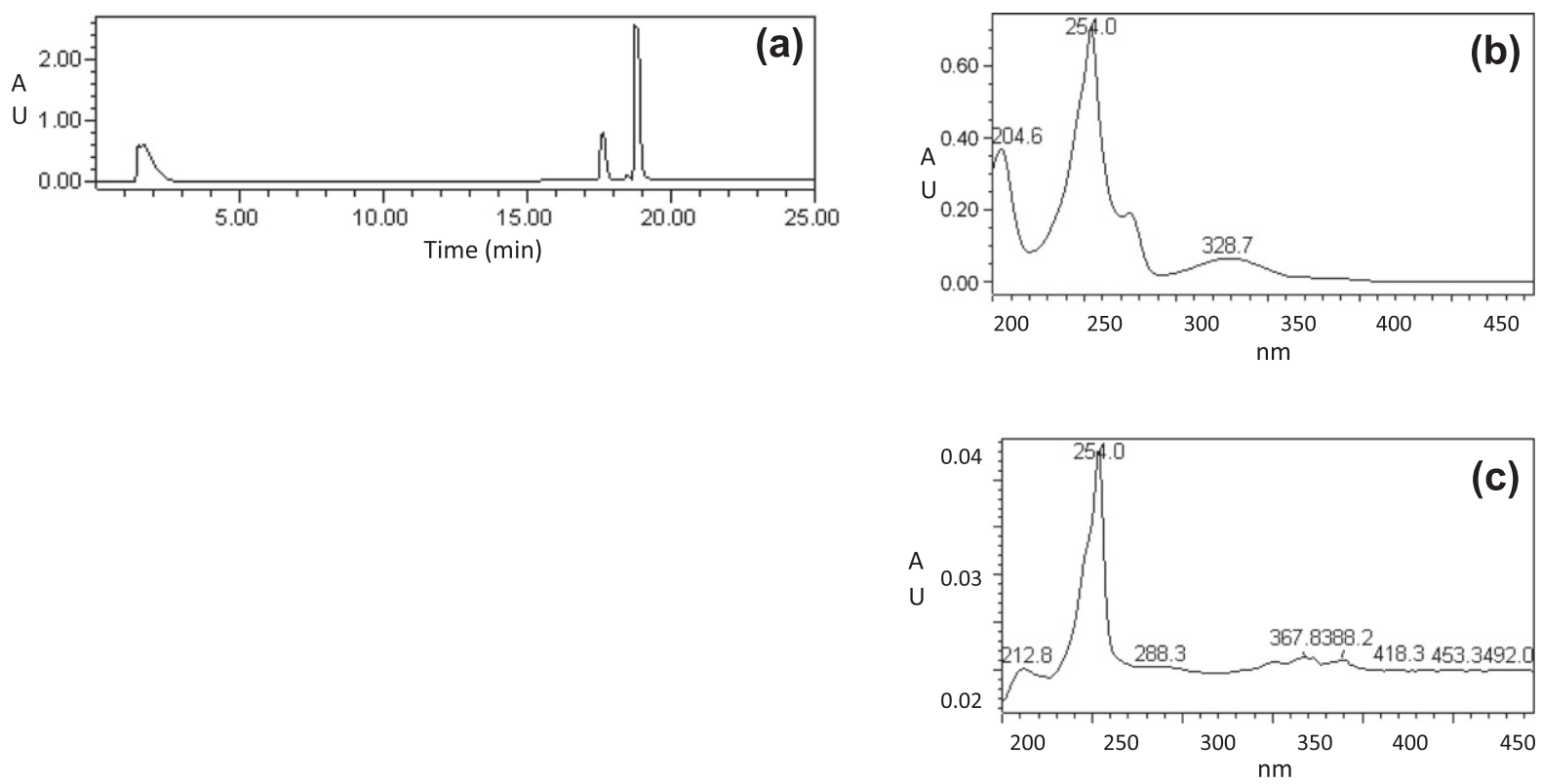

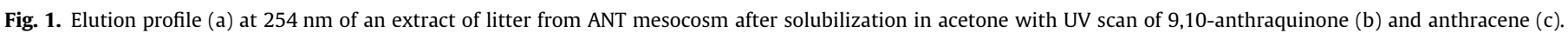


mesocosms with added anthracene (ANT). Furthermore, whatever the experimental conditions, neither lignin-peroxidase activities nor Mn-peroxidase activities were detected (data not shown). This result seems to show that laccases are the principal phenoloxidases involved in aromatic compound degradation in such litters.

Laccase isoform patterns found with PAGE corroborate the results obtained with laccase activity monitoring. We indeed observed an increase in both the number of bands of laccase isoforms and their staining intensity depending on the experimental conditions, corresponding to laccase activity variations. Laccase patterns from control mesocosms showed four bands over time which were weakly stained with Rf $0.55,0.59$ after a 1-month and with Rf 0.42, 0.51 after a 3-month incubation (Table 2). In mesocosms S-C, after the 1-month incubation, two bands with Rf 0.42 and 0.59 were observed while after the 3 -month incubation, five different bands were found (Rf $0.23,0.40,0.47,0.89$ and 0.96 ) and both bands with Rf 0.89 and 0.96 were strongly stained. These two bands are probably linked to the high laccase activity measured after this incubation period in mesocosms S-C (Table 1). The greatest number of bands, out of all the conditions, was obtained in ANT mesocosms after a 3-month incubation: eight strongly stained isoforms were detected with Rf 0.37, 0.51, 0.59, $0.66,0.70,0.87,0.89$ and 0.96 . Isoforms with Rf $0.66,0.70$ and 0.87 were observed only under these conditions. Fig. 2 shows a representative nano-HPLC/tandem mass spectrometry analysis of identified peptides. Twelve precursor ions with monoisotopic masses ranging from 428.58 to 1009.55 were found from MS/MS spectrum. Each MS/MS spectrum was matched against the NCBI non-redundant protein sequence data base. Since no significant hit was obtained (except for contaminant proteins, e.g. trypsin and keratins, data not shown), automatic de novo sequencing was performed. Table 3 lists the different sequences of peptides obtained after de novo sequencing for each monoisotopic mass (m/ $\mathrm{z}$ ). For instance, the precursor ion with $\mathrm{m} / \mathrm{z} 1009.55$ was assigned to only one sequence while the precursor ion with $\mathrm{m} / \mathrm{z} 596.00$ was assigned to three different peptide sequences. MS BLAST homology searches in nrdb95 showed that all these peptides can be assigned to laccase proteins. Table 4 presents the different possible homology matches from MS BLAST which assigned the peptides sequenced to laccases from various fungal species. Among 24 different matches we found that these fungal laccase peptides correspond to genes lac 1, 2, 4, 5, A, C and D, lcc, lcc 1, 2, 3, 4 and 7, pox 1, 2 and 3, and bap. These laccase genes belong to various species

\section{Table 2}

Relative mobility (Rf) of laccase isoforms obtained from Native PAGE in different mesocosms of Pinus halepensis litter: control C, Solvent control S-C, mesocosm with $40 \mathrm{mg}$ of anthracene ANT.

\begin{tabular}{|c|c|c|c|c|c|c|c|}
\hline & \multirow{2}{*}{$\begin{array}{l}\text { Initial } \\
\mathrm{C}\end{array}$} & \multicolumn{3}{|c|}{ 1-Month incubation } & \multicolumn{3}{|c|}{ 3-Month incubation } \\
\hline & & $\mathrm{C}$ & $\mathrm{S}-\mathrm{C}$ & ANT & $\mathrm{C}$ & $\mathrm{S}-\mathrm{C}$ & ANT \\
\hline Rf1 & 0.19 & & & & & & \\
\hline Rf2 & & & & & & 0.23 & \\
\hline Rf3 & 0.33 & & & & & & \\
\hline Rf4 & & & & & & & 0.37 \\
\hline Rf5 & & & & & & 0.40 & \\
\hline Rf6 & & & 0.42 & 0.42 & 0.42 & & \\
\hline Rf7 & & & & & & 0.47 & \\
\hline Rf8 & 0.51 & & & & 0.51 & & 0.51 \\
\hline Rf9 & & 0.55 & & & & & \\
\hline Rf10 & & 0.59 & 0.59 & 0.59 & & & 0.59 \\
\hline \multicolumn{8}{|l|}{ Rf11 } \\
\hline Rf1 2 & & & & & & & 0.66 \\
\hline Rf13 & & & & & & & 0.70 \\
\hline Rf14 & & & & & & & 0.87 \\
\hline Rf15 & & & & & & 0.89 & 0.89 \\
\hline Rf16 & & & & & & 0.96 & 0.96 \\
\hline
\end{tabular}

from Agaricales and Polyporales orders, all of which are Basidiomycota and are either lignocolous fungi such as Trametes spp. or humicolous fungi such as Volvariella volvacea.

\section{Discussion}

In the present study, the percentages of biodegradation of anthracene showed that a high proportion of this organic pollutant (11 mg in mesocosm ANT) was quite rapidly oxidized (within 3 months) by authochtonous microbial communities placed under favorable incubation conditions. Furthermore, an increase in laccase activities was obtained after a 3-month incubation, suggesting that they were strongly induced by anthracene. Steffen et al. (2007) have shown that fungal activities considerably enhanced anthracene transformation in mesocosms. This increase in laccase activities is corroborated by the increased number of laccase isoforms on PAGE in mesocoms with added anthracene. Here, PAGE patterns clearly showed new isoforms when anthracene was added to the mesocosms (mainly isoforms with Rf $0.66,0.70$ and 0.87 ). Laccase activities are known to be induced under various conditions: addition of phenolic compounds (Terróna et al., 2004; Verdin et al., 2006), addition of $\mathrm{CuSO}_{4}$ in the culture (Farnet et al., 1999; Fonseca et al., 2010) or antagonism between microorganisms (Velázquez-Cedeño et al., 2007). Recent studies have also shown that anthracene is responsible for laccase induction in certain fungal species (Farnet et al., 2009). Induction of laccase can lead to the production of new isoforms of these enzymes and/or enhance the production of constitutive isoforms leading to an increase in laccase activity (Edwards et al., 2002; Dodor et al., 2004; Teng et al., 2010). Thus, our results revealed that the laccases produced by fungal communities in the $P$. halepensis litter can be induced by anthracene. The fact that 9,10-anthraquinone was also identified as a product of oxidation of anthracene and that no significant peroxidase activities (LiP and MnP) were detected, suggests that anthraquinone production was essentially due to high laccase activities. The laccases expressed in these litters can thus transform a toxic pollutant, evidence of the major role these enzymes play in both ecosystem functioning and detoxification. This result is in agreement with previous studies which have also identified this product of oxidation in soil mesocosms (Coutiño-González et al., 2010) or in liquid cultures of white-rot fungi (Cañas et al., 2007; Farnet et al., 2009). However, the quantity of 9,10-anthraquinone detected in our study is low in relation to the anthracene degradation yields. This result suggests that 9,10-anthraquinone, a more polar molecule than anthracene, is rapidly further transformed by other microbial enzymes. This finding is of importance since it demonstrates that laccase activities probably enhance aromatic pollutant degradation by authochtonous microbial communities in litter via a first step of oxidation.

It is noteworthy that laccase activities in the $\mathrm{S}-\mathrm{C}$ mesocosms were higher than those in the $\mathrm{C}$ mesocosms. The $\mathrm{S}-\mathrm{C}$ mesocosms were intended to reveal the potential effects on bacterial and fungal communities of residual dichloromethane, which was used as the solvent of anthracene. Although the solvent did evaporate after being added to sub-samples, a certain quantity of this molecule may still have been adsorbed on the litter. Moreover, even when no solvent remained on the litter, it may have chemically reacted with the litter compounds before evaporation. In other words, possible non-target side-effects of solvents used to solubilize apolar pollutants need to be considered in such experiments. Brinch et al. (2002) have emphasized the harmful side-effects of solvents on indigenous microbial consortia. Here, no toxic effects were observed on laccase activity: they were higher in S-C mesocosms than in $\mathrm{C}$ mesocosms, which may mean that dichloromethane extracts from the litter apolar molecules such as phenolic acids or 

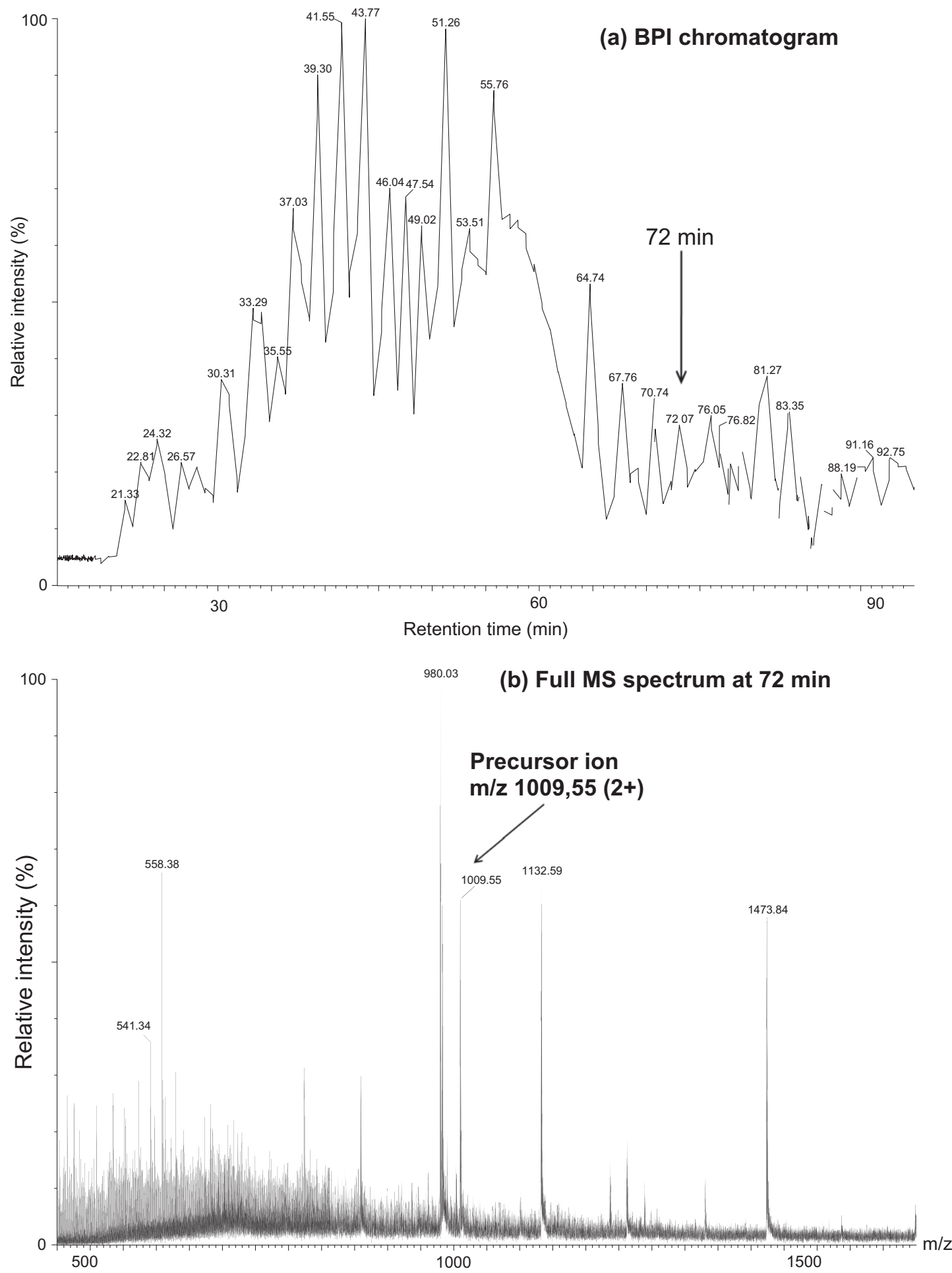

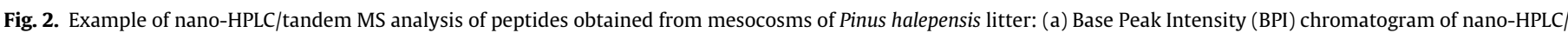

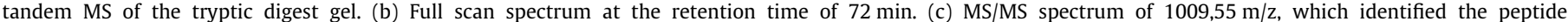
NNSSLDLLNANVAPDGFTR.

tannins, which may induce laccase activities. Moreover, the laccase isoform pattern obtained from the $\mathrm{S}-\mathrm{C}$ mesocosms showed strongly stained bands, which confirms the high level of laccase activities obtained. The strong laccase activities may be also related to the phenolic compounds released by dichloromethane: it has been suggested that these molecules may act as mediators for fungal laccase activities during litter degradation (Calcaterra et al., 2008; Cañas and Camarero, 2010).
While proteomics approaches have an essential role to play in determining changes in microbial function expression under environmental influences (Bastida et al., 2009; Chauhan and Jain, 2010), little work has been done on them. To our knowledge this is the first study focusing on laccase sequencing from proteins produced in litter. The transcript-level gene expression of laccases in forest soils is well documented and reveals both great gene diversity and variations in gene expression (Luis et al., 2004; Kellner 


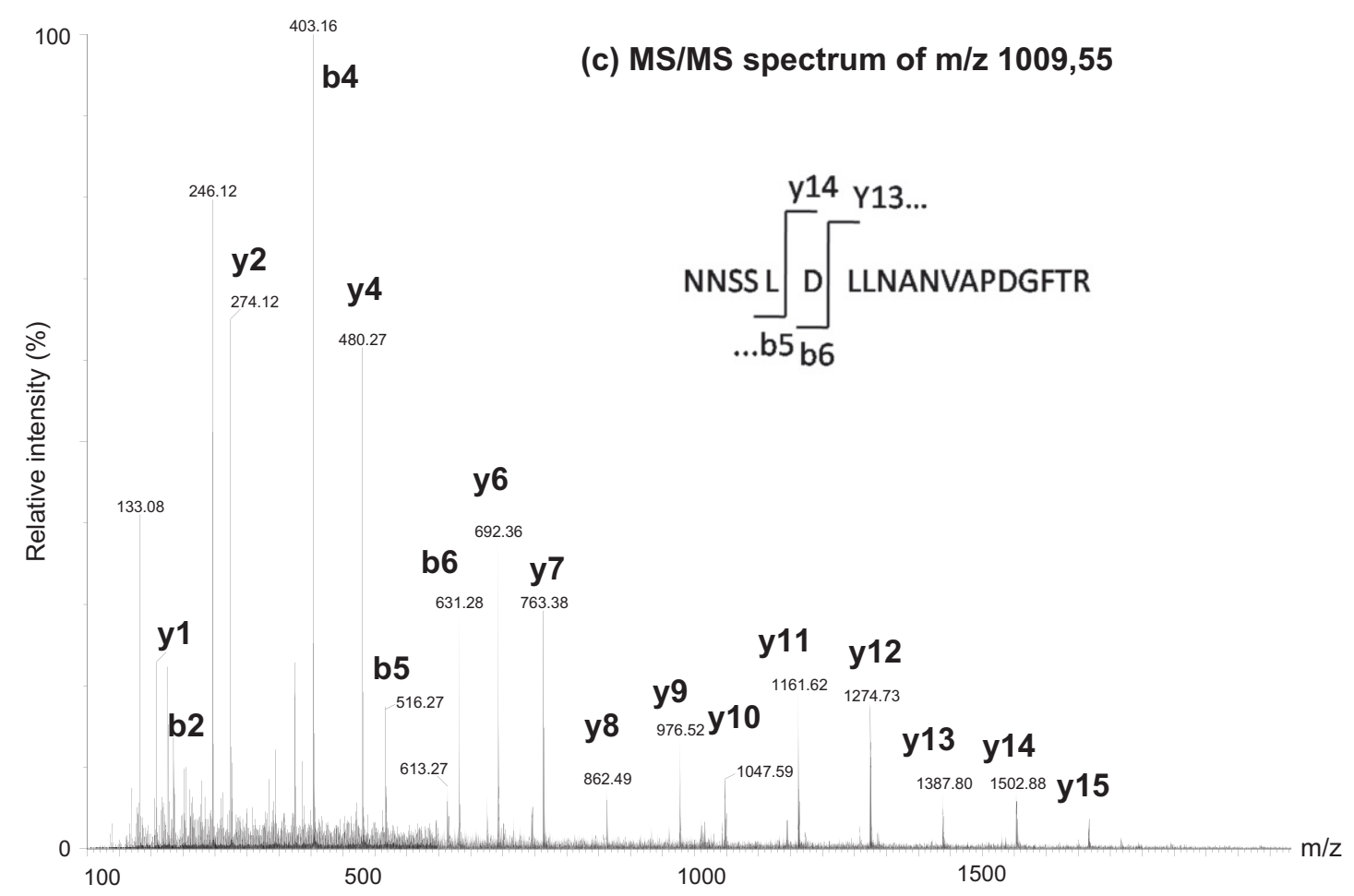

Fig. 2 (continued)

Table 3

Characteristics of peptides from ANT mesocosms after 3 month incubations obtained from HPLC MS/MS and de novo sequencing by Proteinlynx Global software.

\begin{tabular}{|c|c|c|c|}
\hline $\begin{array}{l}\text { Peptide } \\
\text { abbreviation }\end{array}$ & $\begin{array}{l}\text { Sequences obtained by de novo } \\
\text { sequencing }\end{array}$ & $\begin{array}{l}\text { Monoisotopic } \\
\text { mass }(\mathrm{m} / \mathrm{z})\end{array}$ & $\begin{array}{l}\text { Charge } \\
\text { state }\end{array}$ \\
\hline $\mathrm{P}_{1}$ & (-)NNSSLDLLNANVAPDGFTR(-) & 1009.55 & $2+$ \\
\hline$P_{2-1}$ & (-)ANPNPSSRAEFAQLGAR(-) & 596.00 & $3+$ \\
\hline$P_{2-2}$ & (-)ANPNPSSRAEFAAGLGAR(-) & & \\
\hline$P_{2-3}$ & (-)ANPNPTQTAEFAQLGAR(-) & & \\
\hline $\mathrm{P}_{3}$ & $(-)$ VVDTGLFTGQR(-) & 596.81 & $2+$ \\
\hline $\mathrm{P}_{4-1}$ & (-)VVLEELLQLMCR(-) & 428.58 & $3+$ \\
\hline $\mathrm{P}_{4-2}$ & (-)VVLEEQLLLMCR(-) & & \\
\hline $\mathrm{P}_{4-3}$ & (-)VVLEQELLLMCR(-) & & \\
\hline$P_{5-1}$ & $(-)$ LTATTALTAR(-) & 509.77 & $2+$ \\
\hline$P_{5-2}$ & (-)LTATTLTAAR(-) & & \\
\hline$P_{6-1}$ & (-)FTANDVTSTANSTVGDTK(-) & & \\
\hline$P_{6-2}$ & (-)TFANDVTSTANSTVGDTK(-) & 914.92 & $2+$ \\
\hline$P_{6-3}$ & (-)FTANDVTSTANSVTGDTK(-) & & \\
\hline$P_{6-4}$ & (-)TFANDVTSTANSVTGDTK(-) & & \\
\hline $\mathrm{P}_{7}$ & (-)TLTWNYLNSPR(-) & 682.84 & $2+$ \\
\hline $\mathrm{P}_{8}$ & (-)GNASPTPGKCKALVALVGAATPQR(-) & 788.74 & $3+$ \\
\hline$P_{9-1}$ & (-)FNLLGFAVGKNLLDLDTR(-) & 1003.53 & $2+$ \\
\hline $\mathrm{P}_{9-2}$ & (-)FNLLGFAVKGNLLDLDTR(-) & & \\
\hline$P_{9-3}$ & (-)FNLLGFAVGKGGLLDLDTR(-) & & \\
\hline$P_{9-4}$ & (-)FNLLGFAVKGGGLLDLDTR(-) & & \\
\hline $\mathrm{P}_{10}$ & (-)ANPNVGPSGFEKLNTLGLR(-) & 992.53 & $2+$ \\
\hline$P_{11}$ & $(-)$ HLYDVDDK(-) & 502.76 & $2+$ \\
\hline $\mathrm{P}_{12}$ & (-)DPTTVDVPGVR(-) & 564.33 & $2+$ \\
\hline
\end{tabular}

et al., 2009; Kellner and Vandenbol, 2010). However proteomics studies could link the community genetic structure and the functions actually expressed in ecosystems (Kim et al., 2007; Urich et al., 2008). Here we examined laccase expression in litter via direct protein sequencing of the enzymes produced by the whole microbial community and we identify several laccase sequences. It is noteworthy that laccase induction via anthracene made laccase sequencing possible since high laccase activities, up to 800 times higher than in control, was obtained under these experimen- tal conditions. MS BLAST searching shows that the peptides found in the mesocosms with added anthracene, match laccases from different fungal genera: Coprinopsis sp., Pleurotus spp., Trametes spp., Volvariella spp., Rigidoporus spp., Agaricus sp. and Panus sp. (Table 4). However, while matching allowed the peptides found to be identified as laccases, these results have no ecological relevance. In fact, none of these fungi is considered endemic to French Mediterranean coastal habitats. For instance, Volvariella volvacea (Chang and Steinkraus, 1982) is known to be isolated to Asia and Rigidoporus microporus is a pan-tropical species (Corner, 1995). However, among all the different sequences found, it is notable that a sequence was assigned to Basidiomycete C30. This basidiomycete has been isolated from an evergreen oak litter in the Mediterranean area (Tagger et al., 1998) and has been identified as Trametes sp. (Klonowska et al., 2003). Our results are probably affected by a lack of data in the available protein database, which strongly limits assignment to a fungal genus. The full range of fungal species from the Mediterranean area is poorly documented (Laganà et al., 1999), especially those colonizing $P$. halepensis litter in coastal areas. Our study provides information about laccase peptide sequences found in $P$. halepensis litters. These peptide sequences could be useful for further studies focusing on functional genomics for instance to design primers for laccase gene amplification.

These experiments under laboratory conditions should be completed by setting further in situ experiments in order to demonstrate this transformation by microbial communities in natural areas. To better clarify the role of the indigenous microbial community in chronic pollution (Canet et al., 2001; Andreoni and Gianfreda, 2007; Wang et al., 2010) further work should be done on the effect of other recalcitrant molecules which are commonly detected in PAH contamination. Future studies should also investigate whether this detoxification potential is also expressed in inland areas, and whether other litter enzymes are affected by the presence of PAHs. 
Table 4

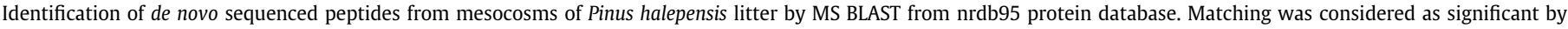
considering the sum of HSPs as described by Shevchenko et al. (2001).

\begin{tabular}{|c|c|c|c|c|c|}
\hline Accession number & Protein & Gene & Microorganism & Query peptides & High Scoring Pairs \\
\hline sptrembl |Q6A1A1|Q6A1A1 & Laccase (EC 1.10.3.2) & lac1 & Pleurotus sapidus & $\begin{array}{l}\mathrm{p}_{1}, \mathrm{p}_{10}, \mathrm{p}_{6-2}, \mathrm{p}_{6-4}, \mathrm{p}_{12}, \mathrm{p}_{3}, \\
\mathrm{p}_{11}\end{array}$ & $\begin{array}{l}66,49,41,41,40,35, \\
35\end{array}$ \\
\hline sptrembl|Q7Z8S6|Q7Z8S6 & Laccase1 (EC 1.10.3.2) & lac1 & Pleurotus sajor-caju & $\mathrm{p}_{1}, \mathrm{p}_{10}, \mathrm{p}_{6-2}, \mathrm{p}_{6-4}, \mathrm{p}_{3}, \mathrm{p}_{11}$ & $71,51,45,45,35,35$ \\
\hline sptrembl |Q69AX8|Q69AX8 & Laccase 1 (EC 1.10.3.2) & led & $\begin{array}{l}\text { Coprinopsis cinerea strain } \\
\text { AmutBmut }\end{array}$ & $\mathrm{p}_{1}, \mathrm{p}_{3}, \mathrm{p}_{2-3}, \mathrm{p}_{6-2}, \mathrm{p}_{6-4}, \mathrm{p}_{4-1}$ & $75,43,43,38,38,34$ \\
\hline swiss |Q12729| LAC1 PLEOS & $\begin{array}{l}\text { Laccase } 1 \text { precursor (EC } \\
1.10 .3 .2 \text { ) }\end{array}$ & pox1 & Pleurotus ostreatus & $\mathrm{p}_{1}, \mathrm{p}_{10}, \mathrm{p}_{6-2}, \mathrm{p}_{6-4}, \mathrm{p}_{11}, \mathrm{p}_{3}$ & $66,45,41,41,40,35$ \\
\hline sptrembl |Q6UNT7|Q6UNT7 & Laccase (EC 1.10.3.2) & lcc & Rigidoporus microporus & $\mathrm{p}_{1}, \mathrm{P}_{7}, \mathrm{P}_{8}, \mathrm{P}_{3}, \mathrm{P}_{11}$ & $70,42,41,35,35$ \\
\hline $\begin{array}{l}\text { sptrembl |Q5MBH3|Q5MBH3 } \\
\text { 9APHY }\end{array}$ & Laccase A & lacA & Trametes sp. 420 & $\mathrm{p}_{1}, \mathrm{p}_{11}, \mathrm{p}_{5-2}, \mathrm{p}_{3}, \mathrm{p}_{4-1}$ & $70,46,37,35,34$ \\
\hline sptrembl | Q69FW9|Q69FW9 & Laccase 5 & lac5 & Volvariella volvacea & $\mathrm{p}_{1}, \mathrm{p}_{10}, \mathrm{p}_{3}, \mathrm{p}_{11}$ & $66,59,35,35$ \\
\hline $\begin{array}{l}\text { sptrembl } \\
\text { |Q5MBH1|Q5MBH1_9APHY }\end{array}$ & Laccase C (EC 1.10.3.2) & lacC & Trametes sp. 420 & $\mathrm{p}_{1}, \mathrm{p}_{11}, \mathrm{p}_{5-1}, \mathrm{p}_{3}$ & $74,46,35,35$ \\
\hline sptrembl | Q69FX0|Q69FX0 & Laccase 3 & lac3 & Volvariella volvacea & $\mathrm{p}_{1}, \mathrm{p}_{11}, \mathrm{p}_{10}, \mathrm{p}_{3}$ & $58,50,47,35$ \\
\hline sptrembl | Q6VMC1|Q6VMC1 & Laccase 3 (EC 1.10.3.2) & $\operatorname{lcc} 3$ & $\begin{array}{l}\text { Coprinopsis cinerea strain } \\
\text { AmutBmut }\end{array}$ & $\mathrm{p}_{1}, \mathrm{p}_{10}, \mathrm{p}_{11}, \mathrm{p}_{3}$ & $65,43,41,35$ \\
\hline sptrembl |Q7Z8S3|Q7Z8S3 & Laccase 4 (EC 1.10.3.2) & lac4 & Pleurotus sajor-caju & $\mathrm{p}_{1}, \mathrm{p}_{10}, \mathrm{p}_{6-2}, \mathrm{p}_{6-4}, \mathrm{p}_{3}$ & $59,49,41,41,35$ \\
\hline swiss |Q12739| LAC2 PLEOS & $\begin{array}{l}\text { Laccase } 2 \text { precursor (EC } \\
1.10 .3 .2)\end{array}$ & pox2 & P.ostreatus & $\mathrm{p}_{1}, \mathrm{p}_{10}, \mathrm{p}_{6-2}, \mathrm{p}_{6-4}, \mathrm{p}_{3}$ & $58,49,41,41,35$ \\
\hline sptrembl |Q6VMC0|Q6VMC0 & Laccase 4 (EC 1.10.3.2) & lcc4 & $\begin{array}{l}\text { Coprinopsis cinerea strain } \\
\text { AmutBmut }\end{array}$ & $\mathrm{p}_{11}, \mathrm{p}_{1}, \mathrm{p}_{3}, \mathrm{p}_{4-1}$ & $55,50,43,34$ \\
\hline sptrembl |Q6VMB7|Q6VMB7 & Laccase 7 (EC 1.10.3.2) & $\operatorname{lcc} 7$ & $\begin{array}{l}\text { Coprinopsis cinerea strain } \\
\text { AmutBmut }\end{array}$ & $\mathrm{p}_{1}, \mathrm{p}_{3}, \mathrm{p}_{11}, \mathrm{p}_{4-1}$ & $58,43,41,34$ \\
\hline sptrembl | Q716A2|Q716A2 & Laccase & pox1 & Trametes sp. I-62 & $\mathrm{p}_{1}, \mathrm{p}_{11}, \mathrm{p}_{10}, \mathrm{p}_{6-1}, \mathrm{p}_{6-2}$ & $58,41,39,34,34$ \\
\hline sptrembl |013422 |013422 & Phenoloxidase (EC 1.10.3.2) & pox3 & Basidiomycete CECT 20197 & $\mathrm{p}_{1}, \mathrm{p}_{11}, \mathrm{p}_{3}, \mathrm{p}_{4-1}$ & $63,40,35,34$ \\
\hline swiss |Q12541|LAC1_ AGABI & $\begin{array}{l}\text { Laccase I precursor (EC } \\
1.10 .3 .2)\end{array}$ & led & Agaricus bisporus & $\mathrm{p}_{11}, \mathrm{p}_{12}, \mathrm{p}_{1}$ & $55,54,53$ \\
\hline swiss | Q12542| LAC2 AGABI & $\begin{array}{l}\text { Laccase II precursor (EC } \\
1.10 .3 .2 \text { ) }\end{array}$ & $\operatorname{lcc} 2$ & Agaricus bisporus & $\mathrm{p}_{11}, \mathrm{p}_{12}, \mathrm{p}_{1}$ & $55,54,53$ \\
\hline sptrembl | Q6RYA5|Q6RYA5 & Laccase (EC 1.10.3.2) & AY450406 & Flammulina velutipes & $\mathrm{p}_{1}, \mathrm{p}_{11}, \mathrm{p}_{10}$ & $68,46,37$ \\
\hline sptrembl |Q8NID5|Q8NID5 & Laccase 2 (EC 1.10.3.2) & lac2 & Basidiomycete C30 & $\mathrm{p}_{1}, \mathrm{p}_{11}, \mathrm{p}_{6-1}, \mathrm{p}_{6-2}$ & $70,46,34,34$ \\
\hline $\begin{array}{l}\text { sptrembl |Q5MP11|Q5MP11_ } \\
\text { 9AGAR }\end{array}$ & $\begin{array}{l}\text { Laccase precursor (EC } \\
1.10 .3 .2 \text { ) }\end{array}$ & pel3 & Pleurotus eryngii & $\mathrm{p}_{1}, \mathrm{p}_{10}, \mathrm{p}_{3}$ & $58,57,35$ \\
\hline $\begin{array}{l}\text { sptrembl |Q5MBH0|Q5MBH0 } \\
\text { 9APHY }\end{array}$ & Laccase D (EC 1.10.3.2) & $l a c D$ & Trametes sp. 420 & $\mathrm{p}_{1}, \mathrm{p}_{11}, \mathrm{p}_{4-1}$ & $69,46,34$ \\
\hline $\begin{array}{l}\text { sptrembl |Q5MBH7|Q5MBH7 } \\
\text { 9APHY }\end{array}$ & Laccase A (EC 1.10.3.2) & lacA & Panus rudis & $\mathrm{p}_{1}, \mathrm{p}_{11}$ & 73,46 \\
\hline
\end{tabular}

\section{Acknowledgments}

This work is dedicated to the memory of Dr. Christopher Augur, Researcher at the Institut de Recherche pour le Développement, IRD. We would like to thank Mrs Marjorie Sweetko for her very helpful assistance in English language and Mrs. Sabrina Lignon from the Proteomics Technical Centre of the Institut de Microbiologie de la Méditerranée (Marseille) for automated protein digestion. This work was supported by a PhD grant from ADEME (Agence de l'Environnement et de la Maîtrise de l'Energie) and the Provence Alpes Côte d'Azur Region (France). We thank the reviewers for their valuable comments.

\section{References}

Andreoni, V., Gianfreda, L., 2007. Bioremediation and monitoring of aromaticpolluted habitats. Appl. Microbiol. Biotechnol. 76, 287-308.

Baldrian, P., 2006. Fungal laccases-occurence and properties. FEMS Microbiol. Rev. $30,215-242$.

Bastida, F. Moreno, J. L., Nicolás, C., Hernández, T., García, C., 2009. Soil metaproteomics: a review of an emerging environmental science. Significance, methodology and perspectives. Eur. J. Soil Sci. 60, 845-859.

Brinch, U.C., Ekelund, F., Jacobsen, C.S., 2002. Method for spiking soil samples with organic compounds. Appl. Environ. Microbiol. 68, 1808-1816.

Calcaterra, A., Galli, C., Gentili, P., 2008. Phenolic compounds as likely natural mediators of laccase: a mechanistic assessment. J. Mol. Catal., B Enzym. 51, $118-120$.

Cañas, A.I., Alcalde, M., Plou, F., Martínez, M.J., Martínez, A.T., Camarero, S., 2007. Transformation of polycyclic aromatic hydrocarbons by laccase is strongly enhanced by phenolic compounds present in soil. Environ. Sci. Technol. 41, 2964-2971.
Cañas, A.I., Camarero, S., 2010. Laccases and their natural mediators: Biotechnological tools for sustainable eco-friendly processes. Biotechno. Adv. 28, 694-705.

Canet, R., Birnstingl, J.G., Malcolm, D.G., Lopez-Real, J.M., Beck, A.J., 2001. Biodegradation of polycyclic aromatic hydrocarbons (PAHs) by native microflora and combinations of white-rot fungi in a coal-tar contaminated soil. Bioresour. Technol. 76, 113-117.

Chang, S.C., Steinkraus, K.H., 1982. Lignocellulolytic enzymes produced by volvariella volvacea, the edible straw mushroom. Appl. Environ. Microb. 43, 440-446.

Chauhan, A., Jain, R.K., 2010. Biodegradation: gaining insight through proteomics. Biodegradation 21, 861-879.

Collins, P.J., Kotterman, M.J., Field, J.A., Dobson, A.D.W., 1996. Oxidation of anthracene and benzo(a)pyrene by laccases from Trametes versicolor. Appl. Environ. Microbiol. 62, 4563-4567.

Corner, H.E.J., 1995. The polypore genera, Henningsia and Rigidoporus. Mycologist. 9, 127.

Coutiño-González, E., Hernández-Carlos, B., Gutiérrez-Ortiz, R., Dendooven, L., 2010. The earthworm Eisenia fetida accelerates the removal of anthracene and 9, 10anthraquinone, the most abundant degradation product, in soil. Int. Biodeterior. Biodegr. 64, 525-529.

Criquet, S., Tagger, S., Vogt, G., Lacazio, G., Le petit, J., 1999. Laccase activity of forest litter. Soil Biol. Biochem. 31, 1239-1244.

De Nicola, F, Maisto, G, Vittoria Prati, M, Alfani, A., 2005. Temporal variations in PAH Concentrations in Quercus ilex L. (holm oak) leaves in an urban area. Chemosphere 61, 432-440.

Dodor, D.E., Hwang, H.M., Ekunwe, S.I.N., 2004. Oxidation of anthracene and benzo [a] pyrene by immobilized laccase from Trametes versicolor. Enzyme Microb. Technol. 35, 210-217.

Edwards, W., Leukes, W.D., Bezuidenhout, JJ., 2002. Ultrafiltration of petrochemical industrial wastwater using immobilised manganese peroxidase and laccase: application in the defouling of polysulphone membranes. Desalination 149, 275-278.

Farnet, A.M., Tagger, S., Le Petit, J., 1999. Effects of copper and aromatic inducers on the laccases of the white-rot fungus Marasmius quercophilus. C.R. Acad. Sci. Paris $322,499-503$ 
Farnet, A.M., Gil, G., Ruaudel, F., Chevremont, A.C., Ferré, E., 2009. Polycyclic aromatic hydrocarbon transformation with laccases of a white-rot fungus isolated from a Mediterranean schlerophyllous litter. Geoderma 14, 267-271.

Farnet, A.M., Chevremont, A.C., Gil, G., Gastaldi, S., Ferré, E., 2011. Alkylphenol oxidation with a laccase from a white-rot fungus: effects of culture induction and of ABTS used as a mediator. Chemosphere. 82, 284-289.

Fonseca, M.I., Shimizu, E., Zapata, P.D., Villalba, L.L., 2010. Copper inducing effect on laccase production of white rot fungi native from Misiones (Argentina). Enzyme Microb. Technol. 46, 534-539.

Hammel, K.E., Kalyanaraman, B., Kirk, T.K., 1986. Oxidation of polycyclic aromatic hydrocarbons and dibenzo[p]-dioxins by Phanerochaete chrysosporium ligninase. J. Biol. Chem. 261, 16948-16952.

Harkin, J.M., Obst, J.R., 1973. Syringaldazine, an effective reagent for detecting laccase and peroxidase in fungi. Experientia 29, 381-387.

Johnsen, A.R., Karlson, U., 2007. Diffuse PAH contamination of surface soils: environmental occurrence, bioavailability, and microbial degradation. Appl. Microbiol. Biotechnol. 76, 533-543.

Kellner, H., Luis, P., Schlitt, B., Buscot, F., 2009. Temporal changes in diversity and expression patterns of fungal laccase genes within the organic horizon of a brown forest soil. Soil Biol. Biochem. 41, 1380-1389.

Kellner, H., Vandenbol, M., 2010. Fungi unearthed: transcripts encoding lignocellulolytic and chitinolytic enzymes in forest soil. PLoS ONE. 5, e10971. doi:10.1371/journal.pone.0010971.

Kim, Y., Nandakumar, M.P., Marten, M.R., 2007. Proteomics of filamentous fungi. Trends Biotechnol. 25, 395-400.

Klonowska, A., Gaudin, C., Ruzzi, M., Chiara Colao, M., Tron, T., 2003. Ribosomal DNA sequence analysis shows that the basidiomycete C30 belongs to the genus Trametes. Res. Microbiol. 154, 25-28.

Laemmli, U.K., 1970. Cleavage of structural proteins during the assembly of the head of bacteriophage T4. Nature 22, 680-685.

Laganà, A., Loppi, S., De Dominicis, V., 1999. Relationship between environmental factors and the proportions of fungal trophic groups in forest ecosystems of the central Mediterranean area. For. Ecol. Manage. 124, 145-151.

Luis, P., Walther, G., Kellner, H., Martin, F., Buscot, F., 2004. Diversity of laccase genes from basidiomycetes in a forest soil. Soil Biol. Biochem. 36, 10251036.

Majeau, J.A., Brar, S.K., Tyagi, R.D., 2010. Laccases for removal of recalcitrant and emerging pollutants. Bioresour. Technol. 101, 2331-2350.

Potin, O., Veignie, E., Rafin, C., 2004. Biodegradation of polycyclic aromatic hydrocarbons (PAHs) by Cladosporium sphaerospermum isolated from an aged PAH contaminated soil. FEMS Microbiol. Ecol. 51, 71-78.

Oria-de-Rueda, J.A., Hernández-Rodríguez, M., Martín-Pinto, P., 2010. Could artificial reforestations provide as much production and diversity of fungal species as natural forest stands in marginal Mediterranean areas? For. Ecol. Manage. 260, 171-180.

Pozdnyakova, N.N., Rodakiowicz-Nowak, J., Turkovskaya, O.V., Haber, J., 2006. Oxidative degradation of polyaromatic hydrocarbons and their derivatives catalyzed directly by the yellow laccase from Pleurotus ostreatus D1. J. Mol. Catal., B Enzym. 41, 8-15.

Quézel, P., Médail, F., 2003. Ecologie et Biogéographie des Forêts du Bassin Méditerranéen. Elsevier, Paris. pp. 572.
Sack, U., Hofrichter, M., Fritsche, W., 1997. Degradation of polycyclic aromatic hydrocarbons by manganese peroxidase of Nematoloma frowardii. FEMS Microbiol. Lett. 152, 227-234.

Shevchenko, A., Wilm, M., Vorm, O., Mann, M., 1996. Mass spectrometric sequencing of proteins silver-stained polyacrylamide gels. Anal. Chem. 68, 850-858.

Shevchenko, A., Sunyaev, S., Loboda, A., Shevchenko, A., Bork, P., Ens, W., Standing K.G., 2001. Charting the proteomes of organisms with unsequenced genomes by MALDI-Quadrupole time-of-flight mass spectrometry and BLAST homology searching. Anal. Chem. 73, 1917-1923.

Sinsabaugh, R.L., 2010. Phenol oxidase, Peroxidase and organic matter dynamics of soil. Soil Biol. Biochem. 42, 391-404.

Sorgi, K., 2007. Monitoring of environmental exposure to polycyclic aromatic hydrocarbons: a review. Environ. Chem. Lett. 5, 169-195.

Steffen, K.T., Schubert, S., Tuomela, M., Hatakka, A., Hofrichter, M., 2007. Enhancement of bioconversion of high-molecular mass polycyclic aromatic hydrocarbons in contaminated non-sterile soil by litter-decomposing fungi. Biodegradation 18, 359-369.

Tagger, S., Périssol, C., Gil, G., Vogt, G., Le Petit, J., 1998. Phenoloxidases of the whiterot fungus Marasmius quercophilus isolated from an evergreen oak litter (Quercus ilex L.). Enzyme Microb. Technol. 23, 372-379.

Teng, Y., Luo, Y., Sun, M., Liu, Z., Li, Z., Christie, P., 2010. Effect of bioaugmentation by Paracoccus sp. strain HPD-2 on the soil microbial community and removal of polycyclic aromatic hydrocarbons from an aged contaminated soil. Bioresour. Technol. 101, 3437-3443.

Terróna, M.C., González, T., Carbajo, J.M., Yagüe, S., Arana-Cuenca, A., Téllez, A. Dobson, A.D.W., González, A.E., 2004. Structural close-related aromatic compounds have different effects on laccase activity and on lcc gene expression in the ligninolytic fungus Trametes sp. I-62. Fungal Genet. Biol. 41, 954-962.

Urich, T., Lanze, A., Qi, J., Huson, D.H., Schleper, C., Schuste, S.C., 2008. Simultaneous assessment of soil microbial community structure and function through analysis of the meta-transcriptome. PLoS ONE. 3, e2527. doi:10.1371/ journal.pone.0002527.

Valentín, L., Kluczek-Turpeinen, B., Willför, S., Hemming, J., Hatakka, A., Steffen, K. Tuomela, M., 2010. Scots pine (Pinus sylvestris) bark composition and degradation by fungi: potential substrate for bioremediation. Bioresour. Technol. 101, 2203-2209.

Velázquez-Cedeño, M., Farnet, A.M., Billette, C., Mata, G., Savoie, J.-M., 2007. Interspecific interactions with Trichoderma longibrachiatum induce Pleurotus ostreatus defence reactions based on the production of laccase isozymes. Biotechnol. Lett. 29, 1583-1590.

Verdin, A., Lounès-Hadj Sahraoui, A., Fontaine, J., Grandmougin-Ferjani, A., Durand R., 2006. Effects of anthracene on development of an arbuscular mycorrhizal fungus and contribution of the symbiotic association to pollutant dissipation. Mycorrhiza 16, 397-405.

Wang, C. Wang, F, Wang, T., Bian, Y, Yang X., Jiang, X, 2010. PAHs biodegradation potential of indigenous consortia from agricultural soil and contaminated soil in two-liquid-phase bioreactor (TLPB). J. Hazard. Mater. 176, 41-47.

Wilck, W., 2007. Global patterns of polycyclic aromatic hydrocarbons (PAHs) in soil. Geoderma. 141, 157-166. 